\title{
Ownership Structure and the Internationalization Process of Publicly-listed Companies in Poland
}

\section{Aleksandra Wąsowska'}

Primary submission: 07.09.12 | Final acceptance: 26.11.12

\begin{abstract}
Purpose: The purpose of this paper is to investigate the relationship between ownership structure and the level and scope of internationalization of Polish listed companies.

Methodology: The analysis is based on quantitative methods (regression analysis).

Findings: The study revealed that there is no statistically significant relationship between concentration of ownership and the internationalization of companies. However, there is a relationship between ownership category and internationalization.

Research implications: The research results suggest that the organizational context (and especially ownership structure) should be taken into account in resource-based theories of internationalization.

Originality: The paper makes three important contributions in the field of International Business. Firstly, it incorporates the organizational context into the resource-based models of internationalization, thus contributing to the debate on the role of ownership structure in the internationalization strategy (Tihanyi et al., 2003) by showing the specific context of an emerging economy at an early stage of its investment development path. Secondly, it is probably the first attempt to analyze the relationship between ownership structure and the internationalization of Polish companies. Thirdly, it presents the results of one of the few research studies conducted in Central and Eastern Europe regarding the specific population of publicly-listed companies.
\end{abstract}

Keywords: ownership structure, internationalization, publicly-listed companies

JEL: F23

\footnotetext{
1 University of Warsaw

Correspodence address: University of Warsaw, Faculty of Managment, Szturmowa 1/3 St., 02-678 Warsaw, e-mail: awasowska@mail.wz.uw.edu.pl.
} 


\section{| Introduction ${ }^{2}$}

In the literature on International Business (hereinafter: IB), the relationship between ownership structure and internationalization is a topic that is relatively rarely discussed. Research studies concerning the determinants of the internationalization of firms have mainly focused on the role of firm-specific advantage (Dunning and Lundan, 2008), which may come from possession of or access to tangible or intangible resources, such as technology, brand or managerial competence. However, the works that have emerged over the past few years suggest that also the organizational context, which consists of factors such as ownership structure and entrepreneurial orientation (Wiklund and Shepherd, 2003), can affect the acquisition and mobilization of resources, and therefore the company's strategy.

The organizational context seems to be particularly important in the internationalization process of companies from emerging economies, traditionally believed to be insufficiently equipped with resources conducive to internationalization. According to Bhaumik et al. (2010, p. 3) "While this was perhaps unimportant within traditional IB theory that has evolved specifically to analyze and explain FDI from the traditional set of source countries in the industrialized world, with the growing visibility of FDI from emerging economies, it is becoming imperative to extend the gamut of analysis to the emerging market MNEs (EMNEs). Yet, little is known about the motivation of emerging market firms to engage in outward FDI, and especially whether the ownership patterns that are an outcome of institutional contexts facilitate or hinder this avenue of their internationalization process".

The purpose of this paper is to answer the question about the nature of the relationship between ownership structure and the level of internationalization of sales as well as the geographic scope of internationalization of capital of Polish listed companies.The paper makes three important contributions in the field of IB. Firstly, it incorporates the organizational context into the resource-based models of internationalization, thus contributing to the debate on the role of ownership structure in the internationalization strategy (Tihanyi et al., 2003) by showing the specific context of an emerging economy at an early stage of its investment development path. Secondly, it is probably the first attempt to analyze the relationship between ownership structure and the internationalization of Polish companies. Thirdly, it presents the results of one of the few research studies conducted in Central and Eastern Europe regarding the specific population of publicly-listed companies, representing a group of the largest and most transparent companies, many of which are leaders of their industries.

The paper is structured as follows: In the second part the theoretical foundations of the research study are discussed. The third part contains the research hypotheses, and in the fourth part the method of sample selection and operationalization of variables is described. In the fifth part the results of statistical analyses are presented, and in the summary the research findings and limitations are discussed.

2 The study is part of research project number NN115259636, funded by the National Science Centre. 


\section{| Theoretical Foundations}

In the literature on the subject a unified theory of the internationalization of firms is yet to be elaborated. Studies on factors stimulating and inhibiting international expansion have led to the emergence of three major theoretical perspectives that describe the determinants of internationalization.

The first one is the traditional theory of foreign direct investment, which is rooted in transaction cost economics. According to the OLI model, firms that have a certain competitive advantage, called the ownership advantage, transfer it to a market that guarantees a location advantage through foreign direct investment, which in turn gives them an internalization advantage. The ownership advantage, defined as the "exclusive privileged possession of, or access to, particular income generating assets" (Dunning, 1988), is based on resources such as fixed assets, factors of production (natural resources, human resources, capital) and intangible resources (knowledge, brand, organizational skills). While ownership advantages determine which firm will internationalize its activities, location advantages determine where the activities will be located. And the choice of location depends on the motives for internationalization. Firms undertake foreign direct investment in the search for natural resources (resource-seeking), markets (market-seeking), efficiency (efficiency-seeking) and strategic assets (strategic asset-seeking) (Dunning and Lundan, 2008). Depending on the firm's internationalization motive, the chosen location should have a sufficiently large market, it should have natural resources, low production costs or access to specific resources, such as technology. The final element of the OLI model is the internalization advantage, which determines the degree of control over foreign activities and the used resources. The reason for foreign direct investment, i.e. capital-related form of internationalization, allowing full control over the foreign activities, is market failure.

The second theoretical perspective places emphasis on resources and capabilities of the firm as the basis for internationalization. The first concept that belongs to this trend was the process approach, pioneered by researchers at the University of Uppsala. According to the Uppsala model internationalization is the process of increasing involvement in operations across borders (Welch and Luostarinen, 1988), where companies usually start their expansion with the sale of their products in markets that are close (in geographical, cultural and institutional terms) to their domestic market. As the firm gains experience in foreign operations (acquiring knowledge and skills), it begins to expand to further markets. Additionally, the firm's commitment to each of the markets it operates in gradually increases, moving from exports to equity-based modes of internationalization (Johanson and Wiedersheim-Paul, 1975).

Another concept of the determinants of the internationalization of firms, stressing the significance of resources and capabilities, is offered by the resource-based view. It sees organizations as bundles of resources, the uneven distribution of which leads to differences in results between firms. Resources can be either tangible or intangible. According the IB researchers, it is the 
intangible resources that are more likely to form the foundation for competitive advantage in foreign markets.

The VRIO model describes the strategies for building competitive advantage based on resources (Barney and Wright, 1998). According to this model, the resources that are the foundation for a sustainable competitive advantage should not only be valuable, rare, inimitable, but also wellorganized. A good organization of resources depends on factors such as the firm's organizational structure, the control systems, the remuneration policy and the ownership structure of the firm. The "O"-factor in the VRIO model thus refers to "orientation, strategy or context" (Newbert, 2007, p. 124), which determine the utilization of the potential of valuable, rare and inimitable resources.

The third perspective describing the determinants of the internationalization of firms is the institutional theory. It stresses the importance of formal institutions and informal constraints that constitute "the rules of the game" in a given society (North, 1990). These include, among other things, tools for the protection of property and contracts, supervision of financial institutions, the transparency of the public sphere and informal institutions that strengthen public confidence. The institutional perspective is the main theoretical framework of research studies on emerging economies, which usually experience rapid changes within their institutions, both formal and informal (Peng et al., 2008).

The three research concepts discussed above are complementary. The OLI model allows to understand the complexity of the internationalization process. The resource-based view adds accuracy to the OLI model, because it indicates the specific resources that can constitute a source of both ownership and location advantage. And finally the institutional perspective draws attention to the dynamics of the external environment in which the process of internationalization takes place. That is why each of these theories can be used to explain the internationalization processes of firms from emerging markets, describing the firm-specific factors that determine the process of internationalization.

One of these factors, perceived both from the institutional and resource-based perspective, is ownership structure. As already mentioned, so far empirical studies in the field of IB have rarely taken on the subject of the impact of ownership structure on internationalization, despite the fact that more and more researchers point out that this factor can have a significant impact on the firm's strategy (George et al., 2005). The significance of ownership structure for the strategy of a firm stems from three key determinants. Firstly, as stressed by the agency theory, the level of concentration of ownership is important, as it has an impact on the propensity to make risky decisions (Burkart et al., 1997), an example of which can be the foreign expansion decision. Secondly, the characteristics of the actual owner are important, since the different goals, modes of operation, preferred use of resources will characterize the financial, industry and individual investors (e.g. family businesses). Thirdly, ownership structure can significantly influence the 
firm's access to resources. An example of such a dependency is the participation of firms in holding companies, which, as shown by the example of Japanese Keiretsu or Korean Chaebol, has a significant impact on the availability of tangible and intangible resources.

Studies on the impact of ownership structure on a firm's strategy have been conducted in the context of the agency theory and mainly concerned the classic problem of the conflict of interests between managers and shareholders (Gedajlovic and Shapiro, 1998). Among the mentioned in the literature on the subject ways to control the agency problem is the participation of managers in the capital structure and the maintenance of a high level of ownership concentration (Shleifer and Vishny, 1997).

There are many works analyzing the impact of ownership concentration on the strategy and results of firms. The positive impact of concentration of capital on the level of expenditure on research and development has been pointed out (Lee and O'Neill, 2003). It has also been suggested that concentrated ownership protects firms against excessive diversification, which often leads to a loss of shareholder value (Amihud and Lev, 1981). Research studies have shown that concentrated ownership facilitates control over the management, at the same time reducing managerial initiative (Aghion and Tirole, 1997) and decreasing the willingness to make risky decisions (Burkart et al., 1997).

Studies on Polish listed companies have shown that the effect of capital concentration on the value of the firm depends on the specificity of the industry (Grosfeld, 2007). In companies of the New Economy, in which the managerial initiative and the ability to take risks are of particular strategic importance, the relationship between the level of ownership concentration and the value of the company is negative. In other industries the concentration of capital is conducive to building shareholder value (Grosfeld, 2007).

While the impact force of the owners on a firm's strategy depends largely on the level of capital concentration, the pursued objectives depend on the "category" (family, institutional investor, bank, etc.) of ownership (Thomsen and Pedersen, 2000). The significance of the "ownership category" as a variable affecting the firm's strategy is an important issue, although it is relatively little explored (Tihanyi et al., 2003). Studies so far have demonstrated that the "ownership category" does have an impact on the access to resources (Shrader and Simon, 1997) and on the degree of risk acceptance (Thomsen and Pedersen, 2000).

Research studies on family ownership (which have been reviewed by e.g. Kowalewski et al., 2010), help identify features differentiating family businesses from firms with a different ownership structure. Family businesses are characterized by low liquidity of shares and poorly diversified financial portfolios (Anderson et al., 2003), which means that they are more exposed to risk and therefore are more likely to take precautionary measures (Filatotchev et al., 2007). Firms that are controlled by their founders (which constitute a specific type of family businesses) are 
less likely to pursue risky strategies (Jensen and Meckling, 1976) and often do not have as many resources, as aversion to risky investments reduces the chances of obtaining new resources, especially intangible resources, such as technology or brand. Family businesses may additionally feel that they lack managerial skills, since they are less likely to hire professional managers than firms with a different ownership structure (Boeker and Karichalil, 2002) and they invest less in training managers (Cromie et al., 1995).

There are also studies that analyze the relationship between "ownership category" and performance. A panel study involving 217 Polish listed companies showed that family ownership has a positive impact on financial results (Kowalewski et al., 2010). However, this correlation disappears above a certain threshold level of family ownership share. When interpreting this result the authors brought up arguments rooted in the agency theory, indicating that family ownership, on the one hand, reduces the costs of supervision, but on the other hand, it can create conditions conducive to acting against the interests of minority investors. Additionally, in the literature on the subject it is suggested that in firms where ownership and management are not separated (proprietorships) there may be problems associated with insufficient capital and risk aversion (Fama and Jensen, 1985). Such firms are less likely to make investments that lead to economies of scale and they often pursue niche strategies.

The presence of institutional investors can reduce the problem of insufficient capital and it also enhances risk resistance. Since an institutional investor (investment or pension fund) is usually an intermediary between the firm and the final investor, his goal is to maximize the return on capital. As suggested by the literature on the subject, institutional investors focus on short-term goals (Porter, 1992). Some researchers indicate an inverse relationship between the share of institutional investors in the capital structure and the level of investment in research and development (Graves, 1988). However, there are studies (McConnell and Servaes, 1990) that demonstrate a positive relationship between institutional ownership and indicators relating to firm performance (Tobin-Q). This correlation also applies to a specific category of institutional investors, i.e. banks.

\section{| Research Hypotheses}

The present research study analyzes the impact of three key variables describing the ownership structure of Polish listed companies - concentration of ownership, the share of individual ownership and the presence of foreign investors - on the internationalization of Polish listed companies.

Concentration of ownership can have a dual effect on the internationalization of firms from emerging markets. On the one hand, it can facilitate international expansion, acting as 
a substitute for external corporate governance mechanisms that can be found in highly developed markets. The owner that controls the listed company has a decisive influence on the choice of investment projects, which makes it possible to avoid conflicts with other shareholders that extend the decision-making process. It can therefore be expected that concentrated ownership is conducive to resolute and bold moves, such as foreign expansion.

However, there are factors that may weaken the positive impact of ownership concentration on internationalization. Firstly, most debuts on the Polish stock market can be observed in times of economic prosperity (1998-1999 and 2005-2007). During these periods owners and managers were characterized by optimism, the prospectuses of firms going public usually indicated internationalization as one of the directions of investment of the capital raised. The economic slowdown in 2001 clearly dampened the sentiments of the investors, who became less willing to make ambitious and risky strategic moves. Secondly, internationalization involves incurring large capital expenditures, high risk, and a slow learning process. In companies with concentrated ownership the owners can avoid making risky decisions regarding the internationalization of their business activity, especially in the face of uncertainties in foreign markets. Given the results of studies showing that concentration of ownership strengthens ownership control, stopping managers from taking risky decisions (Burkart et al., 1997) and weakening the tendency to over-diversify (Amihud and Lev, 1981), one can formulate the following hypothesis:

H.1. a) The degree of ownership concentration is negatively related to the level of internationalization of sales.

H.1. b) The degree of ownership concentration is negatively related to the geographic scope of internationalization of capital.

Individual ownership reduces the costs of supervision, eliminating the strict separation between the functions of ownership, control and management (Shleifer and Vischny, 1997). When these functions are separated, managers may be inclined to undertake geographic diversification, even if it lowers the shareholder value. Based on the agency theory it can therefore be assumed that the presence of an individual investor as the controlling shareholder will stop managers from taking risky decisions, such as decisions about internationalization.

However, on the other hand, there are theoretical arguments that point to the positive impact of individual ownership on the internationalization of firms. Individual investors as the controlling shareholders usually have a greater ability to monitor the firm's operations, and therefore it is believed that they encounter less problems associated with "moral hazard" in foreign markets (Filatotchev et al., 2007). The presence of individual investors (in particular the founders of the firm and members of their families) in the capital structure is also associated with a long-term 
orientation of firms with respect to building a reputation and sustainable long-term growth (Anderson et al., 2003).

Empirical studies examining the relationship between individual ownership and internationalization lead to contradictory results. A research study of listed companies in Taiwan showed a positive correlation between individual ownership and internationalization (Lien et al., 2005). While a recent study of Indian companies showed that a particular kind of individual ownership, i.e. family ownership, has a negative impact on the level of foreign direct investment (Bhaumik et al., 2010). Also studies on small and medium-sized enterprises from highly developed economies indicate a negative impact of family ownership on the level of internationalization (Graves and Thomas, 2006; Fernandez and Nieto, 2006).

Given the ambiguous theoretical arguments and the contradictory research results obtained in various institutional environments, two sets of hypotheses can be formulated:

H.2. a) The presence of an individual investor as the controlling owner is negatively related to the level of internationalization of sales.

H.2. b) The presence of an individual investor as the controlling owner is negatively related to the geographic scope of internationalization.

H.2'. a) The presence of an individual investor as the controlling owner is positively related to the level of internationalization of sales.

H.2'. b) The presence of an individual investor as the controlling owner is positively related to the geographic scope of internationalization.

A final important ownership determinant of the decision about internationalization is the presence of a foreign investor. This helps firms gain knowledge about foreign markets (Fernandez and Nieto, 2006), and becoming part of an international corporation leads to an almost immediate participation in the internal distribution channels of the corporation. That is why analyses concerning the internationalization of the Polish economy show that $54 \%$ of Polish exports is generated by companies controlled by foreign capital (Cieślik, 2010). Hence the hypotheses that:

H.3 a) The presence of a foreign investor as the controlling owner is positively related to the level of internationalization of sales.

H.3 b) The presence of a foreign investor as the controlling owner is positively related to the geographic scope of internationalization of capital. 


\section{Research Method}

Due to the fact that the purpose of this paper is to test hypotheses regarding the relationship between ownership structure and the internationalization of firms, in the analysis quantitative methods will be used in order to enable statistical inference.

Previous research studies on the internationalization of companies from emerging markets point to difficulties in collecting survey data. An additional problem in Poland is the lack of access to the so-called unidentified individual data collected by public statistical institutes (Cieślik, 2010).

Because of these limitations, the present study will be analyzing only listed companies that are subject to the disclosure requirements set out in the Act on Public Trading in Securities. The research study includes Polish companies listed on the Warsaw Stock Exchange in 2006. The primary source of data will be the annual consolidated financial reports of companies as well as the database of the National Court Register (KRS). On 31 December 2006 the Warsaw Stock Exchange had 279 listed domestic companies. After excluding companies from the financial sector as well as companies for which there was no available data, the sample included 202 companies, out of which 78 companies with international capital were selected for statistical analysis.

The research study will be using two dependent variables describing the various aspects of internationalization. The level of internationalization of sales (variable "IL") will be operationalized based on the ratio of foreign sales to total sales. The indicator for the geographic scope of internationalization (variable "IS") will be the number of countries where the firm is involved financially.

The explanatory variables refer to the capital structure, which is usually described in the literature on the subject using two dimensions: concentration of ownership and ownership "category".

The commonly used indicator for the concentration of capital is the voting power of the largest shareholder at the General Meeting of Shareholders (Grosfeld, 2007). This way of operationalization is therefore used in the present research study.

Based on the existing literature on the subject describing the impact of ownership structure of Polish companies on their performance (Grosfeld, 2007), the following owner categories have been identified: the State (State Treasury, local authorities, government agencies), institutional investors (investment funds, insurance funds, pension funds, banks), commercial investors (companies not classified as institutional investors), individual investors (private individuals). Additionally, a category has been introduced based on the participation of foreign investors.

Table 1 presents the ownership structure of the analyzed companies. 
Table 1 | Ownership structure of the analyzed companies

\begin{tabular}{|c|c|c|c|c|c|c|}
\hline \multirow{2}{*}{$\begin{array}{l}\text { Category of the } \\
\text { main investor }\end{array}$} & \multirow{2}{*}{$\begin{array}{c}\text { Total number of } \\
\text { companies }\end{array}$} & \multicolumn{5}{|c|}{$\begin{array}{l}\text { Number of companies, according to the voting power of the main investor } \\
\text { at the General Meeting of Shareholders }\end{array}$} \\
\hline & & $50 \%$ or more & $33 \%-50 \%$ & $20 \%-33 \%$ & $10 \%-20 \%$ & less than 10\% \\
\hline Individual investor & 92 & 26 & 24 & 15 & 23 & 4 \\
\hline Financial investor & 31 & 2 & 8 & 3 & 11 & 7 \\
\hline Commercial investor & 72 & 34 & 18 & 13 & 7 & 0 \\
\hline State Treasury & 5 & 3 & 1 & 1 & 0 & 0 \\
\hline Foreign investor & 38 & 19 & 5 & 9 & 4 & 1 \\
\hline
\end{tabular}

Table 2 | Definition of variables

\section{Variable}

\section{Dependent variables}

Level of internationalization of sales (IL)

Geographic scope of internationalization (IS)

\section{Explanatory variables}

Concentration of ownership (CONCENTRATION)

Main investor - individual (or family) (INDIVIDUAL)

Main investor - foreign (FOREIGN)

\section{Control variables}

Size (SIZE)

Age (AGE)

Industry (INDUSTRY)

Marketing resources (MARKETING)

Technological resources (TECHNOLOGY)

\section{Operationalization}

\section{Foreign sales / total sales}

The number of countries where the firm has foreign direct investments

Voting power of the main investor at the General Meeting of Shareholders (in \%)

0/1 binary variable

0/1 binary variable

Natural logarithm of total assets

Age since registration in the National Court Register (KRS)

Industry affiliation; 0/1 Binary variable

Cost of sales/total sales revenue

Intangibles/fixed assets

Based on the literature on the subject, two ownership categories have been recognized as important in the process of internationalization: individual investors and foreign investors. The variables were dichotomous in nature, where 1 referred respectively to the presence of an individual investor (see La Porta et al., 1999) and a foreign investor as the controlling owner. These categories are not separable, as a foreign investor can be an individual investor at the same time. The controlling owner is considered to be the shareholder with the greatest voting power at the General Meeting of Shareholders, which gives him "effective control" over the company. This study assumes the in the literature on the subject given threshold of $10 \%$ of the voting rights as the minimum share giving "effective control" (La Porta et al., 1999). 
Table 3 | Correlation matrix

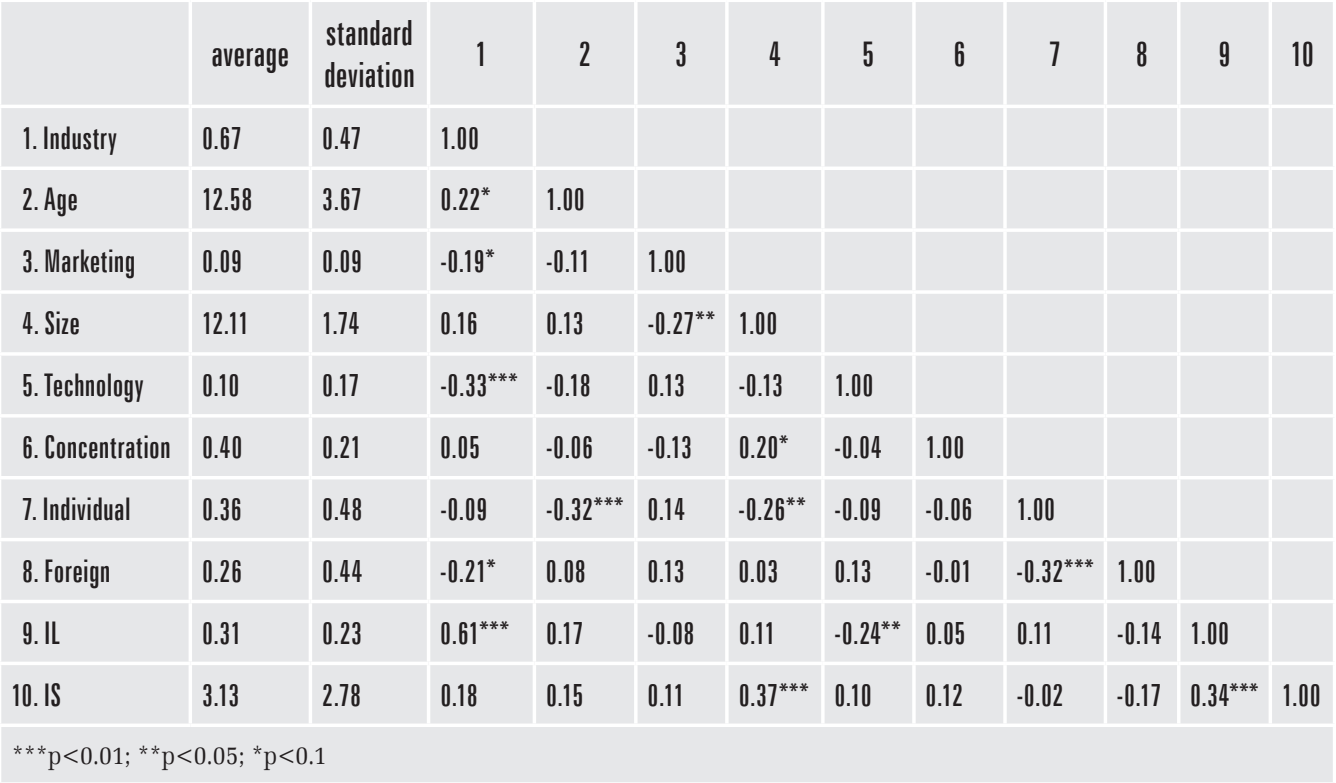

Numerous research studies that have adopted the resource-based perspective have pointed out the importance of technological resources (Grosse and Trevino, 2002) as well marketing resources (Helsen et al., 1993) in building competitive advantage in foreign markets. For this reason, the present research study has included control variables pertaining to these two types of intangible resources. Technological resources have been operationalized based on "soft capital", measured as the share of intangibles in fixed assets (Grosfeld, 2007). Marketing resources have been measured based on the ratio of cost of sales to total sales. The research also includes three other control variables: firm size, age and sectoral (industry) affiliation. Table 2 presents the variables that have been used in the regression analysis as well as their operationalization. Table 3 presents the descriptive statistics and the correlation matrix.

\section{Results}

Below are the results of the estimation of the regression models, separately for the level (Table 4) and scope of internationalization (Table 5).

Model 1 that refers to the level of internationalization (Table 4) includes only control variables, among which the most important one turned out to be industry affiliation. Model 2 includes variables concerning ownership structure. The presence of an individual investor as the controlling owner turned out to be statistically significant and positively correlated with the level of internationalization. 
Table 4 | Regression analysis for IL (level of sales internationalization)

\begin{tabular}{|c|c|c|c|c|}
\hline & \multicolumn{2}{|c|}{ Model 1} & \multicolumn{2}{|c|}{ Model 2} \\
\hline & BETA & standard deviation & BETA & standard deviation \\
\hline Industry & $0.59^{* * *}$ & 0.10 & $0.61^{* * *}$ & 0.10 \\
\hline Age & 0.04 & 0.10 & 0.10 & 0.10 \\
\hline Size & 0.02 & 0.10 & 0.06 & 0.10 \\
\hline Marketing & 0.05 & 0.10 & 0.04 & 0.10 \\
\hline Technology & -0.04 & 0.10 & 0.00 & 0.10 \\
\hline Concentration & & & 0.03 & 0.10 \\
\hline Individual & & & $0.22^{* *}$ & 0.11 \\
\hline Foreign & & & 0.04 & 0.10 \\
\hline R2 & 0.37 & & 0.41 & \\
\hline adj R2 & 0.33 & & 0.34 & \\
\hline$F$ & 8.58 & & 6.03 & \\
\hline
\end{tabular}

Model 1 that refers to the scope of internationalization (Table 5) includes only control variables, among which the most important one turned out to be the size of the firm. Model 2 includes variables associated with ownership structure. Among them the presence of a foreign investor as the controlling owner turned out to be statistically significant and negatively correlated with the scope of internationalization.

The regression analysis allowed for a verification of the hypotheses formulated above, giving the following results:

- There was no statistically significant correlation between the concentration of ownership and the level of internationalization of sales and scope of internationalization. Hypotheses 1a) and 1 b) must therefore be rejected.

- The presence of an individual investor turned out to be positively correlated with the internationalization of sales, while remaining uncorrelated with the scope of internationalization. This result supports hypothesis 2'a), but hypotheses 2a), 2b) and 2'b) must be rejected.

- There was no statistically significant correlation between the presence of a foreign investor and the level of internationalization, and therefore hypothesis 3a) must be rejected. However, this variable turned out to be statistically significant in explaining the scope of internationalization, although the nature of this correlation is just the opposite of what was predicted in hypothesis $3 \mathrm{~b})$. 
Table 5 | Regression analysis for IS (scope of internationalization)

\begin{tabular}{|c|c|c|c|c|}
\hline & \multicolumn{2}{|c|}{ Model 1} & \multicolumn{2}{|c|}{ Model 2} \\
\hline & BETA & standard deviation & BETA & standard deviation \\
\hline Industry & $0.20^{*}$ & 0.11 & 0.17 & 0.11 \\
\hline Age & 0.12 & 0.11 & $0.19^{*}$ & 0.11 \\
\hline Size & $0.42^{* * *}$ & 0.11 & 0.44 & 0.11 \\
\hline Marketing & $0.25^{* *}$ & 0.11 & $0.27^{* *}$ & 0.11 \\
\hline Technology & $0.21^{*}$ & 0.11 & $0.25^{* *}$ & 0.11 \\
\hline Concentration & & & 0.08 & 0.10 \\
\hline Individual & & & 0.11 & 0.12 \\
\hline Foreign & & & $-0.19^{*}$ & 0.11 \\
\hline R2 & 0.26 & & 0.31 & \\
\hline adj R2 & 0.20 & & 0.23 & \\
\hline$F$ & 4.94 & & 3.95 & \\
\hline
\end{tabular}

\section{Conclusions}

The presented analysis contains a number of significant limitations resulting from the specificity of the studied sample and the method of measuring the variables. The studiedsample is limited to Polish listed companies operating in foreign markets. The analysis is cross-sectional, which prevents inferences about cause and effect relationships between the analyzed variables, available only in a longitudinal scheme, which requires building a data panel. Additionally, the in the present research applied way of operationalization of variables is not without simplifications, resulting from the difficulty in measuring the resources and competence of firms, described in many works rooted in the resource-based theory of strategy (Yeoh and Roth, 1999). Despite these limitations, the results of the analysis indicate that ownership structure may have a greater impact on the process of internationalization than assumed in previous theoretical considerations and research studies.

The presence of an individual investor as the controlling owner turned out to be positively related to the internationalization of sales. In the literature on the subject evidence can be found that in a specific institutional context individual ownership can encourage capital expansion. In a study of companies in Taiwan geographic diversification, regarded as a vehicle for sustainable growth and a way to reduce the volatility of cash flows, was positively correlated with individual ownership (Lien et al., 2005). 
A broader interpretation of the positive correlation between individual ownership and internationalization, observed in the case of Polish companies, could refer to the role of the individual investor as an entrepreneur. In the case of young capital markets, the individual investor is often the founder of the firm, listing it on the stock exchange. Maintaining dominant shareholding enables the implementation of the planned strategy of growth, in which one of the steps is to raise capital from financial markets. The fact of a successful listing on the stock exchange of one's own company can be a reflection of the entrepreneurial attitude of the owner.

The special role of individual investors (who are usually the company founders) in the process of internationalization has been pointed out in a qualitative research study conducted among a group of Polish small and medium-sized enterprises entering foreign markets. Individual investors usually make the key decisions associated with the internationalization of the business activity and they monitor foreign transactions. For them, the main source of competence required to operate in foreign markets is learning by doing. When analyzing the process of the internationalization of small and medium-sized enterprises run by individual investors, the authors of the study point to the ability to use fleeting opportunities, openness to knowledge coming from the market, innovativeness and building cooperative relationships with external stakeholders (Koładkiewicz, 2011).

In the literature on the subject entrepreneurial attitude is regarded as an important determinant of the internationalization of firms from emerging markets (Yamakawa et al., 2008). Studies show that in countries in transition to a market economy, entrepreneurship - manifested in innovativeness, entering new markets and the reorganization of resources - plays a key role in the adaptation of firms to the conditions of global competition (Zahra et al., 2000). Moreover, according to the literature on the subject entrepreneurship can compensate for shortages of financial resources and technology (Yamakawa et al., 2008). The observed among the studied Polish listed companies strong correlation between the presence of an individual investor and international expansion, especially considering the insignificance of the selected intangible resources in explaining the level of internationalization of sales, could indicate that the entrepreneurial attitude of the investor is of considerable importance. However, verifying this hypothesis requires more accurate analyses, and in particular an analysis of the entrepreneurial attitudes of individual investors in Polish listed companies.

An alternative interpretation of the obtained results is also possible. The fact that individual ownership coincides with the level of internationalization of sales, while remaining uncorrelated with the scope of internationalization of capital, could mean that firms with individual investors decide to invest abroad only after reaching sufficiently high revenues from foreign sales. A strong sales involvement in foreign markets can in the case of these firms be a prerequisite to undertake more advanced forms of internationalization. The obtained results therefore suggest that individual ownership can foster the phased process of internationalization - the one described in the Uppsala model. 
The presence of a foreign investor as the controlling owner turned out to be statistically significant in explaining the scope of internationalization, but contrary to expectations, the correlation with the variable being explained was negative. Previous studies indicated the important role of foreign capital in the internationalization of Polish companies. For example, in 2003, 54\% of Polish exports of goods were generated by companies controlled by foreign capital (Cieślik, 2010). When interpreting the results obtained in the present study, two aspects should be considered: the nature of the dependent variable, which refers to the internationalization of capital, and not the internationalization of sales, and the specificity of the sample, which includes Polish companies listed on the Warsaw Stock Exchange from non-financial sectors with international capital. Therefore, among the analyzed companies there are no Polish subsidiaries or branches of multinational corporations (greenfield investments), the importance of which in the process of internationalization of the Polish economy is pointed out by Jerzy Cieślik (2010). The results obtained in this study regarding listed companies suggest that the most common objective of foreign investors, who have become the controlling shareholders of Polish listed companies (e.g. Orbis, Budimex, TP SA), was not so much capital expansion through the Polish subsidiaries, but making use of the potential of the Polish market.

Such an interpretation is consistent with the results of qualitative research studies on the direct investment motives in Poland, indicating that there is a relationship between the role of subsidiaries in the value chain of multinational corporations and their market orientation (Gorynia et al., 2005). Polish subsidiaries considered as one of the links in the value chain of multinational corporations were oriented to export, while subsidiaries that had their own, separate value chain focused on the domestic market. A particular group of Polish subsidiaries of multinational corporations, i.e. listed companies that are majority owned by foreign investors, seems to correspond to the second category, which means that they have their own value chain and focus their activities on the domestic market.

$R$ e $f$ e $r$ e $n$ c e $s$

Aghion, P. and Tirole, J. (1997). Formal and real authority in organizations. Journal of Political Economy, 105(1): 1-29.

Amihud, Y. and Lev, B. (1981). Risk reduction as a managerial motive for conglomerate mergers. Bell Journal of Economics, 12(2): 605-617.

Anderson, R., Mansi, S. and Reeb, D. (2003). Founding family ownership and the agency cost of debt. Journal of Financial Economics, 68(2): 263-285.

Barney, J. and Wright, P. (1998). On becoming a strategic partner: the role of human resources in gaining competitive advantage. Human Resource Management, 37(1): 31-46.

Bhaumik S.K., Driffield N. and Pal, S. (2010). Does ownership structure of emerging-market firms affect their outward FDI? The case of the Indian automotive and pharmaceutical sectors. Journal of International Business Studies, 41(3): 437-450.

Boeker, W. and Karichalil, R. (2002). Entrepreneurial transitions: factors influencing founder departure. Academy of Management Journal, 45(2): 818-825.
Burkart, M., Gromb, D. and Panunzi, F. (1997). Large shareholders, monitoring and the value of the firm. Quarterly Journal of Economics, 112(3): 693-728.

Cieślik, J. (2010). Internacjonalizacja polskich przedsiębiorstw. Aktualne tendencje - implikacje dla polityki gospodarczej. Warszawa: Akademia Leona Koźmińskiego.

Cromie, S., Stephenson, B. and Montieth, D. (1995). The management of family firms: an empirical investigation. International Small Business Journal, 13(4): 11-34.

Dunning, J. (1988). The eclectic paradigm of international production: a restatement and possible extensions. Journal of International Business Studies, 19(1): 1-31.

Dunning, J., Lundan, S. (2008). Multinational Enterprises and the Global Economy. Cheltenham: Edward Elgar Publishing.

Fama, E. and Jensen, M. (1985). Organizational forms and investment decisions. Journal of Financial Economics, 14(1): 101-119. 
Fernandez, Z. and Nieto, M. (2006). Impact of ownership on the international involvement of SMEs. Strategic Management Journal, 37(3): 340-351.

Filatotchev, I., Strange, R., Piesse, J. and Lien, Y. (2007). FDI by firms from newly industrialised economies in emerging markets: corporate governance, entry modes and location. Journal of International Business Studies, 38(4): 556-572.

Gedajlovic, E. and Shapiro, D. (1998). Management and ownership effects: evidence from five countries. Strategic Management Journal, 19(6): 533-553.

George, G., Wiklund, J. and Zahra, S. (2005). Ownership and the internationalization of Small Firms. Journal of Management, 31(2): 210-233.

Gorynia, M., Nowak, J. and Wolniak, R. (2005). Motives and modes of FDI, firm characteristics and performance: case studies of foreign subsidiaries in Poland. Journal of Transnational Management, 10(3): 55-87.

Graves, C. and Thomas, J. (2006). Internationalization of Australian family businesses: a managerial capabilities perspective. Family Business Review, 19(3): 207-224.

Graves, S. (1988). Institutional ownership and corporate R\&D in the computer industry. Academy of Management Journal, 31(2): 417-428.

Grosfeld, I. (2007). Struktura własności i wartość spółek notowanych na Giełdzie Papierów Wartościowych w Warszawie. In: B. Błaszczyk and P. Kozarzewski, Zmiany w polskich przedsiębiorstwach. Własność, restrukturyzacja, efektywność. Warszawa: Centrum Analiz Społeczno-Ekonomicznych.

Helsen, H., Jedidi, K. and DeSarbo, W. (1993). A new approach to country segmentation utilizing multinational diffusion patterns. Journal of Marketing, 57: 60-71.

Jensen, M. and Meckling, W. (1976). Theory of the firm: managerial behaviour, agency costs and ownership structure. Journal of Financial Economics, 34(4): 305-360.

Johanson, J. and Wiedersheim-Paul, F. (1975). The internationalization of the firm: four Swedish cases. Journal of Management Studies, 12(3): 305-322.

Koładkiewicz, I. (2011). Aktywność eksportowa polskich przedsiębiorstw z sektora MŚP - dominujące praktyki. In: Koładkiewicz, I., Cieślik, J. (ed.), Aktywność eksportowa małych i średnich przedsiębiorstw w Polsce. Warszawa: Wolters Kluwer Polska.

Kowalewski, O., Talavera, O. and Stetsyuk, J. (2010). Influence of family involvement in management and ownership on firm performance: evidence from Poland. Family Business Review, 23(1): 45-59.

La Porta, R., Lopez-de-Silanes, F. and Shleifer, A. (1999). Corporate ownership around the world. Journal of Finance, 54: s. 471-517.

Lee, P. and O'Neill, H. (2003). Ownership structures and R\&D investments of U.S. and Japanese firms: agency and stewardship perspectives. American Management Journal, 45(2): 212-225.
Lien, Y-C., Piesse, J., Strange, R. and Filatotchev, I. (2005). The role of corporate governance in FDI decisions: evidence from Taiwan. International Business Review, 14: 739-763.

McConnell, J. and Servaes, H. (1990). Additional evidence on corporate ownership and corporate value. Journal of Financial Economics, 27: 595-612.

Newbert, S. (2007). Empirical research on the resource-based view of the firm. An assessment and suggestions for future research. Strategic Management Journal, 28(2): 121-146.

North, D. (1990). Institutions, institutional change and economic performance. Cambridge University Press.

Peng M.W., Wang, D. and Jiang, Y. (2008). An institutionbased view of international business strategy: a focus on emerging economy. Journal of International Business Studies, 39(5): 920-936.

Porter, M. (1992). Capital disadvantage: Americas failing capital market system. Harvard Business Review, 70(5): 65-82.

Shleifer, A. and Vishny R.W. (1997). A survey of corporate governance. Journal of Finance, 52(2): 737-783.

Shrader, R. and Simon, M. (1997). Corporate versus independent new ventures: resources, strategy and performance differences. Journal of Business Venturing, 12(1): 47-66.

Thomsen, S. and Pedersen, T. (2000) Ownership structure and economic performance in the largest European companies. Strategic Management Journal, 21(6): 689-705.

Tihanyi, L., Johnson, R., Hoskisson, R. and Hitt, M. (2003) Institutional ownership differences and international diversification: the effects of boards of directors and technological opportunity. Academy of Management Review, 46(2): 195-211.

Trevino, L. and Grosse, R. (2002). An analysis of firm-specific resources and foreign direct investment in the United States. International Business Review, 11(4): 431-452.

Welch, L.S. and Luostarinen, R. (1988). Internationalization: Evolution of a Concept. Journal of General Management, 14(2): 34-55.

Wiklund, J. and Shepherd, D. (2003). Knowledge-based resources, entrepreneurial orientation, and the performance of small and medium sized businesses. Strategic Management Journal, 24(13): 1307-1314.

Yamakawa, Y., Peng, M. and Deeds, D. (2008). What drives new ventures to internationalize from emerging economies to developed economies. Entrepreneurship Theory and Practice, 32(1): 59-82.

Yeoh, P. and Roth, K. (1999). An empirical analysis of sustained advantage in the US pharmaceutical industry: impact of firm resources and capabilities. Strategic Management Journal, 20(7): 637-653.

Zahra, S., Ireland, D., Gutierrez, I. and Hitt, M. (2000). Privatization and entrepreneurial transformation: emerging issues and a future research agenda. Academy of Management Review, 25(3): 509-524. 